\title{
A PROSPECTIVE STUDY OF PRESENTATIONS OF GASTRIC OUTLET OBSTRUCTION
}

\author{
Prakash S. S1, Raghavendra Prabhu T. $C^{2}$
}

${ }_{1}^{1}$ Assistant Professor, Department of Surgical Oncology, K. R. Hospital, MMC RI, Mysore, Karnataka, India. 2Postgraduate Student, Department of Surgical Oncology, K. R. Hospital, MMC RI, Mysore, Karnataka, India.

\section{BACKGROUND}

\section{ABSTRACT}

Gastric Outlet Obstruction (GOO) also known as pyloric obstruction is not a single entity. It is the clinical and pathophysiological consequence of any disease process that produces a mechanical impediment to gastric emptying.

Aim- To study various diseases presenting as gastric outlet obstruction in Krishna Rajendra Hospital, Mysore attached to Mysore Medical College and Research Institute, Mysore.

\section{MATERIALS AND METHODS}

The patients for this study have been selected from Krishna Rajendra Hospital, Mysore attached to Mysore Medical College and Research Institute, Mysore during the time period of August 2016 to August 2018. Overall, 64 patients have been studied. An elaborate study of the cases with regard to history, clinical features, routine and special investigations, pre-operative treatment, operative findings, post-operative management and complications in the post-operative period is done. Apart from routine surgical profile special investigations like serum electrolytes, barium meal study, upper GI endoscopy and ultrasound abdomen and pelvis were carried out.

\section{RESULTS}

Out of the 64 cases included in our study, 32 patients (50\%) had carcinoma of pyloric antrum, 26 patients (40.6\%) had cicatrised duodenal ulcer, 4 patients $(6.25 \%)$ had corrosive antral stricture and 2 patients $(3.125 \%)$ had gastric outlet obstruction due to carcinoma head of pancreas.

\section{CONCLUSION}

The following conclusions were made in our study: -1. Carcinoma of the antrum of stomach was the commonest cause for Gastric Outlet Obstruction; 2. Age incidence varies between 51-60 years. Patients of 5th and 6th decades were the commonest victims; 3 . Slight male predominance was observed in our study; 4. Vomiting was the commonest presentation of Gastric Outlet Obstruction; 5. UGI scopy was invaluable in diagnosing the aetiology of Gastric Outlet Obstruction.

\section{KEY WORDS}

Gastric Outlet Obstruction, Cicatrised Duodenal Ulcer, Carcinoma Pyloric Antrum.

HOW TO CITE THIS ARTICLE: Prakash SS, Prabhu RTC. A prospective study of presentations of gastric outlet obstruction. J. Evolution Med. Dent. Sci. 2018;7(50):5337-5339, DOI: 10.14260/jemds/2018/1181

\section{BACKGROUND}

Gastric outlet obstruction was described by Sir James Walton as- "The stomach you can hear, the stomach you can feel and the stomach you can see." Gastric Outlet Obstruction (GOO) is the more accurate term for the commonly used term 'pyloric stenosis,' as the site of obstruction is rarely the pylorus itself. The obstruction is usually in the first part of duodenum secondary to cicatrised duodenal ulcer or proximally where the diagnosis of carcinoma is most probable. ${ }^{1}$ Until introduction of effective ulcer therapy $\left[\mathrm{H}_{2}\right.$ receptor blockers and proton pump inhibitors], duodenal ulcer was the most common cause of gastric outlet obstruction. But with increased awareness of the disease, change in the dietary habits and availability of $\mathrm{H}_{2}$ receptor blockers and Proton Pump Inhibitors and recent findings of association of

'Financial or Other Competing Interest': None.

Submission 14-11-2018, Peer Review 27-11-2018,

Acceptance 29-11-2018, Published 10-12-2018.

Corresponding Author:

Dr. Raghavendra Prabhu T. C,

S/o. T. Chikkaiah,

D. No. 139, Sri Raghavendra Krupa,

Havanoor Extension, Bangalore-073,

Karnataka, India.

E-mail: dr_prabhu084@yahoo.co.in

DOI: $10.14260 /$ jemds/2018/1181

\section{(c) $(\mathbf{F})$}

Helicobacter pylori with the causation of peptic ulcer diseases and its effective eradication with $\mathrm{H}$. pylori kits all have resulted in decreased incidence of patients requiring surgery and also the complications like pyloric stenosis have reduced..$^{2}$ At the same time the incidence of antral carcinoma of stomach producing GOO has comparatively increased, which may be due to increased early diagnosis of the condition with the help of flexible fiberoptic endoscope. . $^{3,4}$

This study has been taken up to review the changes in the presentation of gastric outlet obstruction in view of changing trends in the management, because of new drugs and investigatory modalities.

\section{MATERIALS AND METHODS}

A prospective cross-sectional study conducted at KR Hospital, Mysuru, attached to Mysuru Medical College and Research Centre, Mysuru from August 2016 to August 2018. In total, 64 in-patients of gastric outlet obstruction have been studied. Inclusion criteria for the study were patients presenting with gastric outlet obstruction who are treated on an in-patient basis, patients willing for investigations and treatment.

\section{Patients with following were included in Study-}

1. Presence of projectile vomiting of undigested food material, succussion splash heard 3-4 hours after meal, visible gastric peristalsis, presence of mass with above features. 
2. Gastric overnight aspirate of $>200 \mathrm{~mL}$ in fasting state.

3. Positive saline load test: Retention of more than $400 \mathrm{~mL}$ of normal saline 30 minutes after administration of $750 \mathrm{~mL}$ of normal saline.

4. Upper GI scopy (OGD) demonstrating Gastric outlet obstruction.

\section{Exclusion Criteria}

For the study were patients aged 20 years and below, pregnant females, patients with a recent history of any abdominal surgeries.

Detailed history, physical examination and investigation was done in all cases. Saline load test was performed in all cases. Upper gastrointestinal scopy was done in all cases for confirmation of diagnosis. Biopsies were taken wherever required. Barium meal examination was done in 2 cases of corrosive oesophageal stricture as the scope could not be passed beyond. Routine investigations like $\mathrm{Hb} \%$, Bleeding time, Clotting time, Random blood sugar, Blood urea, Serum creatinine, S. electrolytes, Blood grouping and Urine analysis was done in all cases.

\section{RESULTS}

Incidence of gastric outlet obstruction was more between 51-60 yrs. of age. Majority of cases of CA pyloric antrum was noted in the age group of 51-60 yrs. (31.25\%). Obstruction caused due to duodenal ulcer was noted in 41 50 yrs. age group (30.4\%).

$\mathrm{M}$ : $\mathrm{F}$ in carcinoma antrum was 2.2: 1 and $\mathrm{M}$ : $\mathrm{F}$ ratio in cicatrised duodenal ulcer was 3.33: 1.

All (100\%) patients had vomiting of undigested food contents of meals taken earlier.

Loss of appetite was the next major symptom in our study group. $93.75 \%$ of patients with carcinoma antrum complained of weight loss and anorexia. $76.9 \%$ of patients with duodenal ulcer complained of loss of appetite.

Abdominal pain was noted in $71.8 \%$ of patients.

Epigastric mass was palpable in $62.5 \%$ of patients with carcinoma stomach.

$53.8 \%$ of patients with duodenal ulcer were having 0 blood group. $37.5 \%$ of patients with carcinoma stomach had A blood group.

\begin{tabular}{|c|c|c|}
\hline Causes & No. of Patients & Percentage \\
\hline Carcinoma pyloric antrum & 32 & 50 \\
\hline Cicatrised duodenal ulcer & 26 & 40.6 \\
\hline Corrosive antral stricture & 4 & 6.25 \\
\hline Carcinoma head of pancreas & 2 & 3.125 \\
\hline Total & 64 & 100 \\
\hline
\end{tabular}

\begin{tabular}{|c|c|c|}
\hline Age (Years) & No. of Patients & Percentage (\%) \\
\hline $0-10$ & 0 & 0 \\
\hline $11-20$ & 0 & 0 \\
\hline $21-30$ & 4 & 6.25 \\
\hline $31-40$ & 10 & 15.625 \\
\hline $41-50$ & 16 & 25 \\
\hline $51-60$ & 18 & 28.8 \\
\hline $61-70$ & 10 & 15.625 \\
\hline $71-80$ & 6 & 9.375 \\
\hline \multicolumn{3}{|c|}{ Table 2. Age Distribution } \\
\hline
\end{tabular}

\begin{tabular}{|c|c|c|c|c|}
\hline $\begin{array}{c}\text { Age } \\
\text { Group }\end{array}$ & $\begin{array}{c}\text { Carcinoma } \\
\text { Pyloric } \\
\text { Antrum }\end{array}$ & $\begin{array}{c}\text { Cicatrised } \\
\text { Duodenal } \\
\text { Ulcer }\end{array}$ & $\begin{array}{c}\text { Corrosive } \\
\text { Antral } \\
\text { Stricture }\end{array}$ & $\begin{array}{c}\text { Carcinoma } \\
\text { Head of } \\
\text { Pancreas }\end{array}$ \\
\hline $21-30$ & 0 & $2(7.6 \%)$ & $2(50 \%)$ & 0 \\
\hline $31-40$ & $4(12.5 \%)$ & $4(15.2 \%)$ & $2(50 \%)$ & 0 \\
\hline $41-50$ & $8(25 \%)$ & $8(30.40 \%)$ & 0 & 0 \\
\hline $51-60$ & $10(31.25 \%)$ & $6(22.8 \%)$ & 0 & $2(100 \%)$ \\
\hline $61-70$ & $6(18.75 \%)$ & $4(15.2 \%)$ & 0 & 0 \\
\hline $71-80$ & $4(12.5 \%)$ & $2(7.6 \%)$ & 0 & 0 \\
\hline Table 3. Age distribution and causes of Gastric Outlet \\
Obstruction \\
\hline
\end{tabular}

\begin{tabular}{|c|c|c|c|c|c|}
\hline Sex & $\begin{array}{c}\text { Total } \\
\text { No. }\end{array}$ & $\begin{array}{c}\text { Carcinoma } \\
\text { Antrum }\end{array}$ & $\begin{array}{c}\text { Cicatrised } \\
\text { Duodenal } \\
\text { Ulcer }\end{array}$ & $\begin{array}{c}\text { Corrosive } \\
\text { Antral } \\
\text { Stricture }\end{array}$ & Others \\
\hline Males & 44 & 22 & 20 & 2 & 0 \\
\hline Females & 20 & 10 & 6 & 2 & 2 \\
\hline \multicolumn{5}{|c|}{ Table 4. Sex Distribution } \\
\hline
\end{tabular}

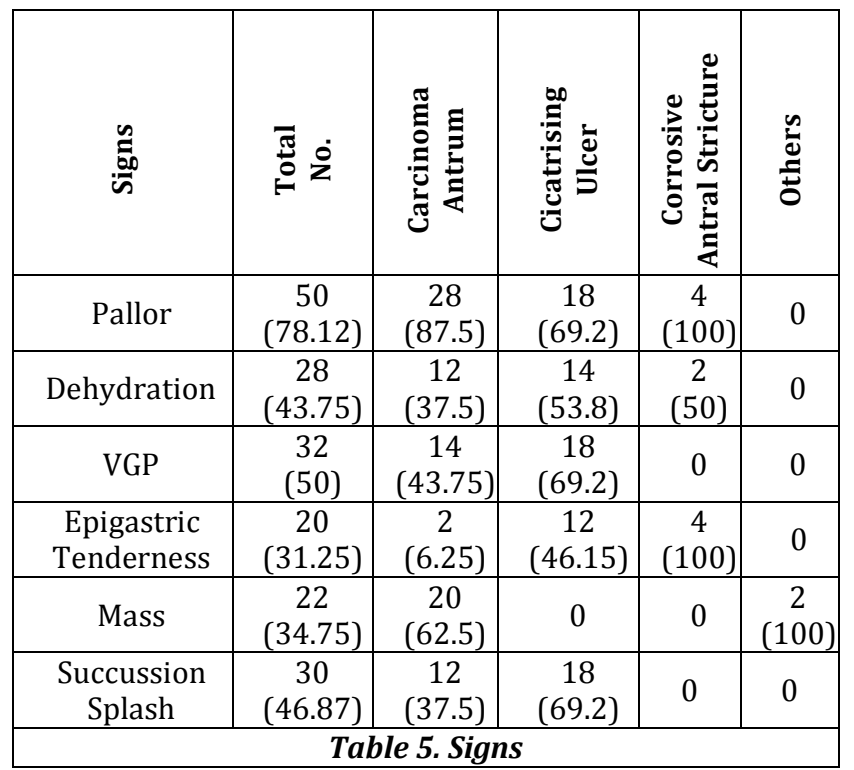

\section{DISCUSSION}

Discussion is mainly on analysis and observation made regarding presenting symptoms, signs, investigations in 64 cases of gastric outlet obstruction admitted to KR Hospital, Mysuru attached to Mysuru Medical College, Mysuru during the time period from August 2016 to August 2018.

Commonest cause of gastric outlet obstruction was carcinoma of pyloric antrum (32) followed by cicatrised duodenal ulcer (26). These results are similar to results of studies conducted by Sukumaran 5 and Godadevi ${ }^{6}$ in India.

Most patients affected due to carcinoma of pyloric antrum were in the age group between 5 th and 7 th decades. Majority $(31.25 \%)$ of the patients presenting with this disease were in the age group of 51-60 years. Maximum incidence of duodenal ulcer sequel patients was noted in age group of 41-50 yrs. (30.4\%).

Male-to-female ratio, GOO was 2.2: 1 overall. Male-tofemale ratio in duodenal ulcer patients was 3.33: 1 and was 2.2: 1 in carcinoma pyloric antrum suggesting predominance of disease in males. In series of Fischer $^{7}$ et al, men outnumbered women by $2: 1$.

Our study showed $65.6 \%$ of patients were smokers and $62.5 \%$ were alcoholics. $76.9 \%$ of patients with duodenal ulcer sequel patients were smokers and $53.8 \%$ were 
alcoholics. These values are similar to study results conducted by Donald D Kozoll and Karl A Meyer ${ }^{8}$ who reported incidence of alcoholism and smoking to be $76.2 \%$ and $52.3 \%$ respectively in their study. This suggests alcohol and tobacco are significant risk factors for causation of duodenal ulcer.

Postprandial vomiting was the main symptom (100\%) in all cases of gastric outlet obstruction, which was projectile in nature with vomitus being partially digested food material. Loss of appetite $(78.12 \%)$ and loss of weight $(62.5 \%)$ were other major symptoms. Abdominal pain was noted in $71.8 \%$ of patients with gastric outlet obstruction. Studies conducted by Yogiram and Chowdhary ${ }^{9}$ and Michael Schwartz ${ }^{10}$ also show abdominal pain, vomiting, loss of weight and appetite as the major presenting complaints.

Weight loss was noted in $59.5 \%$ of patients in series of Donald D Kozoll and Karl A Meyer ${ }^{8}$ and 32\% in series of Harvey J Dworken and Harold P Roth ${ }^{11}$ suggesting weight loss to be significant in patients with pyloric obstruction. Loss of weight (87.5\%) was present in majority of patients in our study.

Majority (87.5\%) of patients with carcinoma stomach were anaemic, probably due to less amount of nutrition and microscopic blood loss and cancer cachexia. Yogiram and Chowdhary ${ }^{9}$ noted the presence of visible gastric peristalsis in $74 \%$ of patients. Visible gastric peristalsis was noted in $43.75 \%$ of patients with carcinoma antrum.

Succussion splash was seen in $69.2 \%$ of patients with cicatrising duodenal ulcer. Succussion splash was not a major (37.5\%) finding in patients with malignancy, which is similar to observation made by Harold Ellis. ${ }^{12}$

$37.5 \%$ of patients with carcinoma pyloric antrum belonged to ' $A$ ' blood group. Blood group ' $O$ ' was the major $(53.8 \%)$ group noted in patients with cicatrising duodenal ulcer.

This is significant as persons with ' $O$ ' blood group are about three times more likely to develop acid peptic disease.

\section{CONCLUSION}

Commonest cause of gastric outlet obstruction in our study was carcinoma of pyloric antrum followed by cicatrised duodenal ulcer. Two cases were due to corrosive stricture and one due to carcinoma head of pancreas. Recent studies show that carcinoma pyloric antrum has replaced cicatrised duodenal ulcer as a leading cause of gastric outlet obstruction. The incidence of obstruction due to carcinoma of pyloric antrum is more common in recent times as per our study results, most probably due to successful treatment of duodenal ulcers by drugs such as proton pump inhibitors, H.pylori kit and early diagnosis of carcinoma pylorus due to newer investigatory modalities. Gastric outlet obstruction is more in males than females. It is associated with smoking and alcohol consumption, vomiting of undigested food consumed earlier was the commonest symptom. Majority of GOO with duodenal ulcer sequel were of blood group ' $O$ ' and carcinoma pyloric antrum patients were of blood group ' $A$ '.

\section{REFERENCES}

[1] Cuschieri A, Hanna GB. Essential surgical practice: higher surgical training in general surgery. $5^{\text {th }}$ edn. Hodder Arnold 2013: p. 565.

[2] Dempsey D, Ashley S, Mercer DW, et al. Peptic ulcer surgery in the H. pylori era: indications for operation. Contemp Surg 2001;57:434-41.

[3] Williams NS, Bullstrode CJK, O'Connell PR. Bailey and Love's: short practice of surgery. $26^{\text {th }}$ edn. Hodder Arnold 2013: p. 1036-55.

[4] Shone DN, Nikoomanesh P, Smith-Meek MM, et al. Malignancy is the most common cause of gastric outlet obstruction in the era of $\mathrm{H} 2$ blockers. American Journal of Gastroenterology 1995;90(10):1769-70.

[5] Sukumar V, Ravindran C, Prasad RV. Demographic and etiological patterns of gastric outlet obstruction in Kerala, South India. North American Journal of Medical Sciences 2015;7(9):403-6.

[6] Godadevi TSRSVR, Reddy RA. A clinical study and management of gastric outlet obstruction in adults. Int J Sci Stud 2016;4(6):104-8.

[7] Fischer RD, Ebert PA, Zuidema GD. Obstructing peptic ulcers. Results of treatment. Arch Surg 1967;94(5):724-7.

[8] Kozoll DD, Meyer KA. Obstructing gastroduodenal ulcers: general factors influencing incidence and mortality. Archives of Surgery 1964;88(5):793-9.

[9] Yogiram B, Chowdary NVS. Duodenal (ulcer) stenosis in Andhra Pradesh. A 10 year study. Ind J Surg 1983: p. 12-6.

[10] Schwartz MC. Gatric outlet obstruction in peptic ulcer disease, an indication for surgery. Am J Surgery 1982;143:90.

[11] Dworken HJ, Roth HP. Pyloric obstruction associated with peptic ulcer: a clinicopathological analysis of 158 surgically treated cases. JAMA 1962;180(12):1007-10.

[12] Ellis H. Pyloric stenosis. In: Nyhus LM, Wastell C, eds. Surgery of the stomach and duodenum. $4^{\text {th }}$ edn. Boston: Little Brown Publications 1986: p. 475. 